\title{
Cyperus Iria Aqueous-Ethanol Extract Ameliorated Hyperglycemia, Oxidative Stress and Regulated Inflammatory Cytokines in Streptozotocin Induced Diabetic Rats
}

\section{Myeda Saeed}

University of Lahore - Defence Road Campus: The University of Lahore - New Campus

Ali Sharif ( $\sim$ alisharif.pharmacist@gmail.com )

Lahore College for Women University Institute of Pharmacy: Lahore College for Women University Faculty of Pharmaceutical and Allied Health Sciences https://orcid.org/0000-0003-4721-4762

\section{Saeed UlHassan}

Imran Idrees College of Pharmacy

\section{Bushra Akhtar}

University of Agriculture Faisalabad

\section{Faqir Muhammad}

University of Agriculture Faisalabad

Maryam Malik

The University of Lahore

\section{Research Article}

Keywords: Cyperus iria, Oxidative stress, Anti-inflammatory, Streptozotocin, Antihyperglycemic

Posted Date: February 24th, 2021

DOI: https://doi.org/10.21203/rs.3.rs-216684/v1

License: (c) (1) This work is licensed under a Creative Commons Attribution 4.0 International License. Read Full License

Version of Record: A version of this preprint was published at Environmental Science and Pollution Research on August 20th, 2021. See the published version at https://doi.org/10.1007/s11356-021-159179. 


\section{Abstract}

Present study is involved in identification of biophenolic and flavonoids from the aqueous-ethanol extract of Cyperus iria and appraisal of inflammatory and stress markers involved in endocrine dysfunction based upon its folktale use. Significantly higher quantities of phenolic ( $82.79 \pm 0.003 \mathrm{mg} / \mathrm{g} \mathrm{GAE})$ and flavonoid (13.61 $\pm 0.002 \mathrm{mg} / \mathrm{g}$ QE) contents were present. Inhibitory concentration (IC50) exhibited an excellent potential for both antioxidant (IC50 $=3.22 \mu \mathrm{g} / \mathrm{mL}$ ) and alpha amylase (IC50 $=36.29 \mu \mathrm{g} / \mathrm{mL}$ ) inhibitory assays. High performance liquid chromatography (HPLC), confirmed the existence of myercetin, quercetin, kaempferol and ferullic acid. Cyperus iria aqueous-ethanol extract exhibits good tolerance against glucose. Streptozotocin induced hyperglycemia declined along with improvement in inflammatory (TNF-a $=15.6 \pm 0.2 \mathrm{~g} / \mathrm{l}, \mathrm{COX}-2=357 \pm 0.396 \mathrm{U} / \mathrm{l}, \mathrm{IL}-6=572 \pm 0.99 \mathrm{pg} / \mathrm{l}$ ) and oxidative stress markers (SOD $=163 \pm 0.616$ and $\mathrm{GSH}-\mathrm{ST}=95.8 \pm 0.44 \mathrm{U} / \mathrm{mL}$ ) along with biochemical parameters in a dose-dependent manner. Present study suggests that Cyperus iria aqueous-ethanol extract possess hypoglycemic potential which might be attributed to the presence of phenolics and flavonoids.

\section{Introduction}

Diabetes mellitus is a disorder with disrupted metabolism, associated with hyperglycemia due to inadequate insulin production or insulin resistance. Extracellular hyperglycemia and intracellular hypoglycemia results due to reduced tissue uptake of glucose (Asmat et al. 2016). There are many possible causes of type 2 diabetes mellitus but specific etiology remains unknown. Different agents are available for the treatment of diabetes. Mostly patients suffering from diabetes mellitus are overweight and have fat accumulation in the abdominal region. Obesity itself causes insulin resistance up to some extent (Sabry et al. 2019).

Besides, therapeutically active pharmaceutical compounds, a wide range of plants have medicinal properties (Barkaoui et al. 2017). The modern medicines isolate active compounds from plants to aid the health care system. Almost $50 \%$ of the current medicines being used are herbal based (Kamboj 2000). With the increasing prevalence of diabetes, the need for new strategies arise to combat the growing silent epidemic, leading towards the use of plant-derived drugs owing to their less risk of adverse reactions. World Health Organization (WHO) has approved the usage of conventional plant managements for diabetes mellitus as they are potent, non-toxic, showing lesser or no adverse reactions due to this reason they are considered to be worthy candidates to be used as an oral treatment (Manukumar et al. 2017)

Cyperus iria, locally known as rice flatsedge belongs to family Cyperaceae. Trigonal, thin and smooth stems are possessed by Cyperus iria that are 1-2 $\mathrm{mm}$ in width and can reach up to $60 \mathrm{~cm}$ in height (Semwal et al. 2016). Different synonyms for Cyperus iria are Chlorcyperus iria, Cyperus microiria. Cyperus microlepis, Cyperus pamicoides and Cyperus santonici. According to the folklore tales, the whole plant of Cyperus iria possesses antihyperglycemic activity (Banik et al. 2010). 
The objective of the present study was to investigate the in-vitro and in-vivo antihyperglycemic activity of Cyperus iria. To the best of our knowledge no study was conducted in aspect of its antihyperglycemic potential till date.

\section{Materials And Methods}

\subsection{Plant Gathering and Authentication:}

The whole plant of Cyperus iria was gathered from different rice fields and wetlands of Lahore, Pakistan during month of May and June 2018. Plant sample was authenticated by Botany Department of Government College University, Lahore. A voucher with specimen number GC.Herb.Bot.3526 was deposited in the department's herbarium unit for future reference. The gathered plant was thoroughly washed and air-dried in shade. After 15 days the dried plant was grounded to powder with the help of an electronic grinder.

\subsection{Preparation of Plant Extract:}

Extract was prepared through cold maceration using ethanol and distilled water (1:3 w/v). named as aqueous-ethanol extract of Cyperus iria. The filtered extract was dried in rotary evaporator and oven. The dried crude extract was reserved in glass vials for further investigation.

\subsection{Phytochemical Analysis:}

The aqueous-ethanol extract of Cyperus iria was tested for phytochemicals according to the protocols described previously by (Zaib et al. 2020).

\subsection{Total Phenolic Contents:}

Total phenolic contents were estimated by Folin Ciocalteu's method (Zaib et al. 2020). Different dilutions $(20 \mathrm{mg} / \mathrm{mL}, 40 \mathrm{mg} / \mathrm{mL}, 60 \mathrm{mg} / \mathrm{mL}, 80 \mathrm{mg} / \mathrm{mL}, 100 \mathrm{mg} / \mathrm{mL}$ and $120 \mathrm{mg} / \mathrm{mL})$ of gallic acid and aqueousethanol extract of Cyperus iria were prepared. The experiment was performed in triplicate. Absorbance was measured at 760nm using UV-spectrophotometer. The phenolic contents were measured as gallic acid equivalent (GAE) and expressed as (GAE mg/g of Cyperus iria aqueous-ethanol extract)

\subsection{Total Flavonoid Contents:}

Total flavonoid content was measured with the aluminum chloride colorimetric assay (Ahmed et al. 2017). Different dilutions ( $20 \mathrm{mg} / \mathrm{mL}, 40 \mathrm{mg} / \mathrm{mL}, 60 \mathrm{mg} / \mathrm{mL}, 80 \mathrm{mg} / \mathrm{mL}, 100 \mathrm{mg} / \mathrm{mL}$ and $120 \mathrm{mg} / \mathrm{mL}$ ) of standard Quercetin and aqueous-ethanol extract of Cyperus iria were prepared from the stock solution. The absorbance was measured at $415 \mathrm{~nm}$ using UV-visible spectrophotometer. Flavonoid contents were measured as quercetin equivalent (QE) and expressed as (QE $\mathrm{mg} / \mathrm{g}$ of Cyperus iria aqueous-ethanol extract) (Zulfqar et al. 2020).

\subsection{High Performance Liquid Chromatography(HPLC) analysis:}


The phytochemical quantification of aqueous-ethanol extract of Cyperus iria was conducted using HPLC system LC-10 Shimadzu (koyoto, Japan). HPLC system was equipped with a photodiode array (PDA) detector SPD-10AV and a UV visible detector (280 nm wavelength) along with pump (LC-10AT). A CLCODS(C-18) shim pack column $(25 \mathrm{~cm} \times 4.6 \mathrm{~mm}, 5 \mu \mathrm{m})$ was used. Two mobile phases, A (Water; acetic acid (94:6, $\mathrm{pH} 2.27)$ and $\mathrm{B}(100 \%$ acetonitrile) with a flow rate of $1 \mathrm{~mL} / \mathrm{min}$ were used as gradients. The sample results were evaluated by comparison with the standard peaks used as reference (Zafar et al. 2020).

The concentration of detected flavonolic and phenolic compounds were calculated from the calibration curve by formula:

concentration of sample $=\frac{\text { Area of sample }}{\text { Area of standard }} \times$ concentration of standard

\subsection{Investigation of in-vitro Antioxidant Activity by DPPH Assay:}

The antioxidant capacity of aqueous-ethanol Cyperus iria extract was carried out by using DPPH assay (Razzaque et al. 2020). Different dilutions of $20 \mathrm{mg} / \mathrm{mL}, 40 \mathrm{mg} / \mathrm{mL}, 60 \mathrm{mg} / \mathrm{mL}, 80 \mathrm{mg} / \mathrm{mL}, 100 \mathrm{mg} / \mathrm{mL}$ and $120 \mathrm{mg} / \mathrm{mL}$ were prepared from the stock solution of plant extract and ascorbic acid. The absorbance was measured by UV spectrophotometer at wavelength of $517 \mathrm{~nm}$. The inhibitory concentration was calculated from prepared inhibition curve. Radical scavenging activity was measured by:

\%age inhibition $=\frac{\text { Positive control }- \text { standard or extract }}{\text { Positive control }} \times 100$

\subsection{Investigation of in-vitro Antioxidant Activity by Phosphomolybdenum Reduction Assay:}

The total antioxidant capacity (TAC) of aqueous-ethanol extract of Cyperus iria was analyzed using phosphomolybdenum complex forming assay. Different dilutions of concentrations $20 \mathrm{mg} / \mathrm{mL}$, $40 \mathrm{mg} / \mathrm{mL}, 60 \mathrm{mg} / \mathrm{mL}, 80 \mathrm{mg} / \mathrm{mL}, 100 \mathrm{mg} / \mathrm{mL}$ and $120 \mathrm{mg} / \mathrm{mL}$ were prepared from the stock solutions of plant extract and standard ascorbic acid. The absorbance of the samples was measured at $695 \mathrm{~nm}$ using a UV spectrophotometer. The antioxidant capacity was measured and expressed in $\mu \mathrm{g}$ of ascorbic acid equivalents (AAE) per $\mathrm{mL}$.

\subsection{Estimation of in-vitro Inhibitory a-amylase Assay:}


In-vitroanti diabetic activity was estimated using a-amylase inhibition assay. The plant extract and standard acarbose solutions were prepared in different concentrations of $20 \mathrm{mg} / \mathrm{mL}, 40 \mathrm{mg} / \mathrm{mL}$, $60 \mathrm{mg} / \mathrm{mL}, 80 \mathrm{mg} / \mathrm{mL}, 100 \mathrm{mg} / \mathrm{mL}$ and $120 \mathrm{mg} / \mathrm{mL}$. Absorbance was measured at $540 \mathrm{~nm}$ (Razzaque et al. 2020). The inhibitory concentration was calculated from prepared inhibition curve. The \%age inhibition of a-amylase activity was measured by,

$$
\text { Inhibitory activity of } \alpha \text { amylase }=\frac{A c-A_{e} \text { or } A_{s}}{A c} \times 100
$$

Where,

$A_{c}=$ Control's absorbance

$A \rrbracket=$ Standard's absorbance

$\mathrm{A} \mathrm{Q}=$ Extract's absorbance

\subsection{Experimental Animals:}

Albino-Wistar rats of either gender $(200 \mathrm{~g}-250 \mathrm{~g})$ were kept in cages under standard conditions $\left(20-25^{\circ} \mathrm{C}\right)$, fed with standard pellet food and water ad libitum. An ethical approval of the experimental protocol was obtained from the Institutional Research Ethics Committee (IREC-2018-63) of the University of Lahore and the experiments were conducted according to these institutional guidelines.

\subsection{Acute Toxicity Study:}

Acute oral toxicity was performed according to the Organization of Economic Cooperation and Development (OECD) 423 guidelines. Wistar rats were divided into 4 groups. Rats were administered with single dose of $200 \mathrm{mg} / \mathrm{kg}, 2000 \mathrm{mg} / \mathrm{kg}$ and $5000 \mathrm{mg} / \mathrm{kg}$ aqueous-ethanol extract of Cyperus iria each along with normal control group. The dose was administered in 12-h fasted rats through oral gavage. After administration, the rats were carefully observed for behavioral patterns at $0.5,4,16,24$ and 48 hours. After 48 hours, the animals were dissected for the histopathological examination of liver and pancreas.

\subsection{Oral Glucose Tolerance Test (OGTT):}

24 hours fasted wistar rats of either sex were selected. The blood glucose level was measured and hyperglycemia was induced with glucose solution, followed by the administration of metformin (500 $\mathrm{mg} / \mathrm{kg}$ ) and extract at dose levels of 125, 250 and $500 \mathrm{mg} / \mathrm{kg} \mathrm{BW}$. Glucose level was monitored at Omin $30 \mathrm{~min}, 60 \mathrm{~min}, 90 \mathrm{~min}, 120 \mathrm{~min}, 180 \mathrm{~min}$ and $210 \mathrm{~min}$ by withdrawing blood sample from the tip of tail vein using a glucometer. Anti-hyperglycemic inhibition was calculated following the protocol of (Amuri et al. 2017) 


\subsection{Experimental design:}

NCG: Negative control group $(\mathrm{n}=5)$ received normal saline $(1 \mathrm{ml} / \mathrm{kg})$ orally

DCG: Diabetic control group $(\mathrm{n}=5)$ diabetes induced by streptozotocin $(\mathrm{STZ})(55 \mathrm{mg} / \mathrm{kg})$, nicotinamide $(110 \mathrm{mg} / \mathrm{kg})$ intraperitoneal

PCG: Positive control group $(n=5)$ administered metformin orally in dose of $500 \mathrm{mg} / \mathrm{kg}$ after inducing diabetes.

E125: Treatment group $(\mathrm{n}=5)$ administered $125 \mathrm{mg} / \mathrm{kg}$ aqueous-ethanol extract of Cyperus iria after inducing diabetes.

E250: Treatment group $(n=5)$ that were administered $250 \mathrm{mg} / \mathrm{kg}$ aqueous-ethanol extract of Cyperus iria after inducing diabetes.

E500: Treatment group $(\mathrm{n}=5)$ that were administered $500 \mathrm{mg} / \mathrm{kg}$ aqueous-ethanol extract of Cyperus iria after inducing diabetes.

\subsection{Induction of diabetes}

Wistar rats were starved over-night. Freshly prepared nicotinamide $(110 \mathrm{mg} / \mathrm{kg} \mathrm{BW})$ dissolved in normal saline was administered intraperitoneal (IP) and after a $15 \mathrm{~min}$ interval STZ (55 mg/kg BW) dissolved in 0.1 molar (M) citrate buffer ( $\mathrm{pH}$ 4.5) was injected in a single dose intraperitoneally. The rats were given $5 \%$ dextrose solution overnight after the STZ administration to avoid hypoglycemic shock. The blood glucose levels were assessed by drawing blood from the tail vein by an Accu-Check glucometer (Roche). After 72 hours of STZ administration, the rats having glucose level exceeding $250 \mathrm{mg} / \mathrm{dL}$ were selected for the study and considered diabetic (Zafar et al. 2020)

\subsection{Anti-Hyperglycemic Activity:}

After the induction of diabetes, the rats were monitored for 15 days. The rats were given their accurate, freshly prepared doses by an oral gavage tube, once a day. The fasting blood glucose levels were checked at 0, 3, 6. 9, 12 and 15 days using an Accu-Check glucometer (Roche, Switzerland).

\subsection{Estimation of Inflammatory Cytokines:}

Pro-inflammatory cytokines were measured in the serum samples of all treated groups. Rat Eliza kits K1052, K4145 and E4801 were used to evaluate Tumor Necrosis Factor alpha (TNF-a), Interleukin-6 (IL-6) and Cyclooxygenase-2 (COX-2) respectively according to manufacturer instructions Bio vision, Inc, 
California. The Serum samples were allowed to clot for $30 \mathrm{~min}$ in serum separator tubes followed by centrifugation at approximately $3000 \times \mathrm{g}$ for $10 \mathrm{~min}$ (Malik et al. 2020).

\subsection{Estimation of Antioxidant Enzymes:}

The activity of defense antioxidants superoxide dismutase (SOD) and Glutathione S-transferase (GSHST) were measured in plasma samples of animals using commercial kits obtained from Nanjing Jiancheng Bioengineering Institute China as per manufacturer's instructions. Blood sample $(3 \mathrm{~mL})$ was collected in heparinized tubes from each rat. It was centrifuged for $10 \mathrm{~min}$ at $1000 \mathrm{rpm}$ at $4^{\circ} \mathrm{C}$. Plasma as supernatant (yellow layer) was cautiously drawn and positioned on icepack (Sharif et al. 2016b).

\subsection{Biochemical Parameters:}

Overnight fasted rats were sacrificed by euthanasia. Blood was collected by direct heart puncture. The separated serum was stored at $-20^{\circ} \mathrm{C}$ for further analysis of its biochemical parameters including liver function tests, renal function tests and lipid profile (Khan et al. 2020).

\subsection{Histopathology}

The liver, kidney, and pancreas of treated and control groups were dissected out, and rinsed with ice-cold saline solution. These organs were preserved in $10 \%$ neutral formalin solution. Paraffin blocks were prepared after being washed, dehydrated with alcohol and cleared by xylene. A rotary microtome was used for cutting sections with a thickness of 4-5 $\mathrm{mm}$ and stained with hematoxylin and eosin. The slides were observed for histopathological changes under light microscope (optika vision lite 2.1) (Sharif et al. 2016a).

\subsection{Statistical analysis:}

The results are expressed as mean $\pm S D$. The $I C_{50}$ was calculated by non-linear regression model using Graph Pad Prism 6.0. Significant difference was assessed between diabetic control and experimental groups. One-way analysis of variance (ANOVA) was performed using Graph Pad Prism 5.0 software followed by Tukey's test and probability level $p<0.05$ was considered statistically significant. The oral glucose tolerance test was evaluated by measuring area under the curve (AUC).

\section{Results}

\subsection{Phytochemical Analysis:}


Phytochemical analysis revealed the presence of alkaloids, glycosides, flavonoids, phenols, carbohydrates, fixed oils, proteins, and terpenoids in the aqueous-ethanol extract of Cyperus iria.

\subsection{Total Phenolic Contents:}

The total phenolic contents in aqueous-ethanol extract of Cyperus iria were found to be $82.79 \mathrm{mg} / \mathrm{g} \mathrm{GAE}$, Regression equation was used to determine the phenolic contents. $y=0.0119 x+0.1577, R^{2}=0.9849$.

\subsection{Total Flavonoid Contents:}

The total flavonoids contents in aqueous-ethanol extract of Cyperus iria were found out to be $13.61 \mathrm{mg} / \mathrm{g}$ QE. Regression equation was used to determine the flavonoid contents. $y=0.0261 x+0.0083, R^{2}=0.9775$.

\subsection{High Performance Liquid Chromatography (HPLC) analysis:}

HPLC analysis confirmed the presence of Myercetin (0.0037ppm), Quercetin (1.757ppm), Kaempferol $(0.0318 \mathrm{ppm})$, Ferulic acid $(6.00 \mathrm{ppm})$ in aqueous-ethanol extract of Cyperus iria Results are depicted in Table 1.

Table 1

Phyto-constituents identified in aqueous-ethanol extract of Cyperus iria

\begin{tabular}{|lllll|}
\hline \multicolumn{1}{|c|}{$\begin{array}{l}\text { Concentration } \\
\text { (ppm) }\end{array}$} & $\begin{array}{l}\text { Retention time } \\
(\mathbf{m i n})\end{array}$ & $\begin{array}{l}\text { Area } \\
(\mathbf{m A U}) \mathbf{s})\end{array}$ & $\begin{array}{l}\text { Area } \\
(\%)\end{array}$ \\
\hline Flavonolic compounds & & & \\
\hline Myercetin & 0.0037 & 4.16 & 2.23673 & 3.3315 \\
\hline Quercetin & 1.757 & 5.793 & 55.88739 & 83.2402 \\
\hline Kaempferol & 0.0318 & 8.413 & 9.01580 & 13.4284 \\
\hline Phenolic compound & & & \\
\hline Ferullic acid & 6.00 & 4.534 & 103.82788 & 100.00 \\
\hline
\end{tabular}

3.5 Investigation of in-vitro Antioxidant Activity by DPPH Assay:

Inhibitory concentration of aqueous-ethanol extract of Cyperus iria was found out to be $39.88 \mu \mathrm{g} / \mathrm{mL}$. Ascorbic acid was used as standard $\left(\mathrm{IC}_{50}=3.22 \mu \mathrm{g} / \mathrm{mL}\right)$. Results are depicted in Table 2 . 
Table 2

\%age inhibition of DPPH analysis at different concentration of aqueous-ethanol extract of Cyperus iria and $\mathrm{IC}_{50}$ values

\begin{tabular}{|c|c|c|c|c|}
\hline $\begin{array}{l}\text { Concentration } \\
(\mu \mathrm{g} / \mathrm{ml})\end{array}$ & $\begin{array}{l}\text { \%age inhibition of } \\
\text { ascorbic acid }\end{array}$ & $\begin{array}{l}\text { IC四 } \\
\text { value } \\
(\mu \mathrm{g} / \mathrm{ml})\end{array}$ & $\begin{array}{l}\text { \%age inhibition of aqueous-ethanol } \\
\text { extract of Cyperus iria }\end{array}$ & $\begin{array}{l}\text { IC财 } \\
\text { value } \\
(\mu \mathrm{g} / \mathrm{ml})\end{array}$ \\
\hline 10 & $74.00 \pm 0.176$ & \multirow[t]{6}{*}{3.22} & $75.40 \pm 0.055$ & \multirow[t]{6}{*}{39.88} \\
\hline 20 & $78.04 \pm 0.001$ & & $78.40 \pm 0.006$ & \\
\hline 40 & $79.03 \pm 0.001$ & & $79.50 \pm 0.016$ & \\
\hline 60 & $79.60 \pm 0.006$ & & $80.18 \pm 0.003$ & \\
\hline 80 & $80.00 \pm 0.010$ & & $81.20 \pm 0.004$ & \\
\hline 100 & $82.09 \pm 0.005$ & & $83.00 \pm 0.002$ & \\
\hline
\end{tabular}

TAC of aqueous-ethanol extract of Cyperus iria was found to be $20.04 \mathrm{mg} / \mathrm{g}$ Ascorbic acid equivalent (AAE). Regression equation was used to determine TAC. $y=0.0072 x-0.0319, R^{2}=0.977$.

\subsection{Estimation of in-vitro Inhibitory Alpha-amylase Assay:}

Inhibitory concentration of aqueous-ethanol extract of Cyperus iria for alpha amylase was found out to be $36.29 \mu \mathrm{g} / \mathrm{mL}$. Acarbose was used as standard $\left(\mathrm{IC}_{50}=5.710 \mu \mathrm{g} / \mathrm{mL}\right)$. Results are depicted in Table 3 .

Table 3

\%age inhibition of a-Amylase analysis at different concentration of aqueous-ethanol extract of Cyperus iria and $\mathrm{IC}_{50}$ values

\begin{tabular}{|c|c|c|c|c|}
\hline $\begin{array}{l}\text { Concentration } \\
(\mu \mathrm{g} / \mathrm{ml})\end{array}$ & $\begin{array}{l}\text { \%age inhibition of } \\
\text { acarbose }\end{array}$ & $\begin{array}{l}\text { ICW } \\
\text { value } \\
(\mu \mathrm{g} / \mathrm{ml})\end{array}$ & $\begin{array}{l}\text { \%age inhibition of aqueous-ethanol } \\
\text { extract of Cyperus iria }\end{array}$ & $\begin{array}{l}\text { IC讴 } \\
\text { value } \\
(\mu \mathrm{g} / \mathrm{ml})\end{array}$ \\
\hline 10 & $71.875 \pm 0.024$ & \multirow[t]{6}{*}{5.710} & $3.125 \pm 0.001$ & \multirow[t]{6}{*}{36.29} \\
\hline 20 & $81.400 \pm 0.003$ & & $8.590 \pm 0.008$ & \\
\hline 40 & $92.960 \pm 0.003$ & & $15.625 \pm 0.001$ & \\
\hline 60 & $93.750 \pm 0.001$ & & $20.310 \pm 0.007$ & \\
\hline 80 & $94.530 \pm 0.003$ & & $22.650 \pm 0.008$ & \\
\hline 100 & $96.090 \pm 0.005$ & & $24.210 \pm 0.006$ & \\
\hline
\end{tabular}

\subsection{Acute Toxicity Study:}


Different behavioral parameters observed were observed and depicted in Table 4. No mortality in rats was observed up to $5000 \mathrm{mg} / \mathrm{kg}$ dose of Cyperus iria aqueous-ethanol extract in acute toxicity study. However liver and kidney section revealed moderate degeneration of hepatocytic cells and $\beta$-cells respectively.

Results are depicted in Fig. $5(1,2)$

Table 4

Effect of Cyperus iria aqueous-ethanol extract on behavioral patterns in rats

\begin{tabular}{|llllllllllll|}
\hline Behavioral Patterns & \multicolumn{2}{ll}{ Observations } & & & & & & \\
\hline & 30 min & 4 hours & 16 hours & 24 hours & 48 hours \\
\hline Eyes & TG & CG & TG & CG & TG & CG & TG & CG & TG & CG \\
\hline Fur and skin & N & N & N & N & N & N & N & N & N & N \\
Sleep & N & N & N & N & N & N & N & N & N & N \\
Convulsions & P & P & P & P & P & P & P & P & P & P \\
\hline Itching & N.F & N.F & N.F & N.F & N.F & N.F & N.F & N.F & N.F & N.F \\
\hline Respiration & N.F & N.F & N.F & N.F & N.F & N.F & N.F & N.F & N.F & N.F \\
\hline Salivation & N & N & N & N & N & N & N & N & N & N \\
\hline Urine & N & N & N & N & N & N & N & N & N & N \\
\hline Feces & N & N & N & N & N & N & N & N & N & N \\
\hline Coma & N & N & N & N & N & N & N & N & N & N \\
\hline Mortality & N.F & N.F & N.F & N.F & N.F & N.F & N.F & N.F & N.F & N.F \\
\hline CG = Control group, TG & N.F & N.F & N.F & N.F & N.F & N.F & N.F & N.F & N.F & N.F \\
\hline
\end{tabular}

\subsection{Oral Glucose Tolerance Test (OGTT):}

Oral glucose tolerance test was performed on normoglycemic rats. Area under curve (AUC) was calculated by plotting concentration of glucose against time interval. The aqueous-ethanol extract of Cyperus iria at the concentration $500 \mathrm{mg} / \mathrm{kg}$ exhibited maximum anti-hyperglycemic inhibition of $15.45 \%$ achieving a Cmax of $244 \mathrm{mg} / \mathrm{dL}$ within 60 min which is close to the positive control group (Fig. 3A)

\subsection{Anti-Hyperglycemic Activity:}

Dose dependent decrease in hyperglycemia was observed when rats were treated with different concentrations of aqueous-ethanol extract of Cyperus iria. The results were analyzed by means of oneway analysis of variance (ANOVA) which displayed statistically significant difference $(p<0.001)$ in contrast with the diabetic control group (Fig. 1). 


\subsection{Estimation of Inflammatory Cytokines:}

Concentrations of pro inflammatory mediators were raised in STZ induced diabetic rats when compared to normal control group. Upon treatment with aqueous-ethanol extract of Cyperus iria levels of TNF-a, IL-6 and COX-2 were reduced exhibiting an improvement in the levels of inflammatory cytokines. A dose dependent effect was observed. (Fig. 2A, B, C)

\subsection{Estimation of Antioxidant Enzymes:}

SOD and GSH-ST activity in STZ induced diabetic rats was declined to $163 \pm 0.616$ and $95.8 \pm 0.44$ in plasma respectively, when compared to the activity in the control rats. Aqueous-ethanol extract of Cyperus iria restored the SOD and GSH-ST activity in treated rats in a dose-dependent fashion. (Fig. 2D, E)

\subsection{Biochemical Parameters:}

Present study indicated that aqueous-ethanol extract of Cyperus iria reduced the levels of alkaline phosphatase (ALP), aspartate aminotransferase (AST), Alanine Aminotransferase (ALT) depicted in Fig. 3B, triglycerides (TG), low density lipoproteins (LDL), total cholesterol (TC) (Table 5) urea and creatinine (Table 6) insulin and $C$ reactive proteins (CRP) depicted in Fig. $2(F, G)$ in STZ induced diabetic rats. An increase in high density lipoproteins $(\mathrm{HDL})$ and insulin levels was observed. 
Table 5

Effect of Cyperus iria aqueous-ethanol extract on lipid profile of streptozotocin induced diabetic rats

\begin{tabular}{|c|c|c|c|c|c|c|}
\hline Parameter & Mean test $\mathrm{V}$ & ues (mg/dL) & & & & \\
\hline & NCG & PCG & DCG & E125 & E250 & E500 \\
\hline Total lipids & $347 \pm 1.17$ & $374 \pm 1.46$ & $\begin{array}{l}448 \pm \\
1.02\end{array}$ & $\begin{array}{l}422 \pm \\
0.860^{*}\end{array}$ & $400 \pm 2.13^{\star *}$ & $\begin{array}{l}388 \pm \\
1.98^{* \star \star}\end{array}$ \\
\hline Cholesterol & $71.4 \pm 1.50$ & $86.2 \pm 1.50$ & $\begin{array}{l}205 \pm \\
2.42\end{array}$ & $\begin{array}{l}133 \pm \\
1.10^{\star \star \star}\end{array}$ & $\begin{array}{l}123 \pm \\
1.02^{\star \star \star}\end{array}$ & $\begin{array}{l}98.8 \pm \\
0.73^{\star \star \star}\end{array}$ \\
\hline Triglycerides & $76.2 \pm 1.28$ & $\begin{array}{l}86.2 \pm \\
0.583\end{array}$ & $\begin{array}{l}132 \pm \\
1.52\end{array}$ & $\begin{array}{l}121 \pm \\
0.374^{*}\end{array}$ & $\begin{array}{l}115 \pm \\
0.812^{\text {}}\end{array}$ & $\begin{array}{l}101 \pm \\
1.38^{\star \star \star}\end{array}$ \\
\hline HDL & $\begin{array}{l}28.8 \pm \\
0.374\end{array}$ & $\begin{array}{l}22.8 \pm \\
0.735\end{array}$ & $\begin{array}{l}16 \pm \\
0.447\end{array}$ & $\begin{array}{l}17.6 \pm \\
0.678^{\star}\end{array}$ & $18.8 \pm 1.30^{*}$ & $\begin{array}{l}21 \pm \\
0.548^{\star \star \star}\end{array}$ \\
\hline LDL & $34 \pm 1.18$ & $54 \pm 1.30$ & $\begin{array}{l}171 \pm \\
2.68\end{array}$ & $\begin{array}{l}128 \pm \\
2.35^{\star \star \star}\end{array}$ & $\begin{array}{l}93.4 \pm \\
2.16^{\star \star \star}\end{array}$ & $67 \pm 0.89^{\star \star *}$ \\
\hline VLDL & $17.6 \pm 0.5$ & $29.6 \pm 0.6$ & $\begin{array}{l}32.8 \pm \\
0.58\end{array}$ & $36.6 \pm 0.51$ & $34.4 \pm 0.678$ & $32 \pm 0.316$ \\
\hline
\end{tabular}

Values are expressed as Mean $\pm \operatorname{SEM}(\mathrm{n}=5)$. * shows $p<0.05, * \star p<0.01, * \star \star p<0.001$ in comparison to diabetic control group DCG.

Table 6

Effect of Cyperus iria aqueous-ethanol extract on renal profile of streptozotocin induced diabetic rats

\section{Parameter Mean test values $(\mathrm{mg} / \mathrm{dL})$}

$\begin{array}{lllllll} & \text { PCG } & \text { NCG } & \text { DCG } & \text { E125 } & \text { E250 } & \text { E500 } \\ \text { Urea } & 38 \pm 0.44 & 31.6 \pm 0.92 & 49 \pm 0.54 & 50.2 \pm 0.86 & 44.8 \pm & 41 \pm 0.63^{\star \star \star} \\ & & & & & 0.66^{\star \star} & \\ \text { Creatinine } & 0.676 \pm & 0.454 \pm & 0.968 \pm & 0.898 \pm & 0.824 \pm & 0.68 \pm \\ & 0.016 & 0.015 & 0.01 & 0.003^{\star} & 0.01^{*} & 0.02^{\star \star \star}\end{array}$

Values are expressed as Mean \pm SD $(n=5)$. ${ }^{*}$ shows $p<0.05$, $* * p<0.01$, $* \star * ~ p<0.001$ in comparison to diabetic control group DCG.

\subsection{Histopathology:}

Histological alterations presented by diabetic control group were reversed significantly upon treatment with Cyperus iria aqueous-ethanol extract. Liver sections of diabetes induced group when treated with Cyperus iria aqueous-ethanol extract $500 \mathrm{mg} / \mathrm{kg}$ revealed normal architecture of tissue, similarly in kidney section Restoration of focal degeneration of proximal tubules was observed whereas pancreatic tissue revealed normal looking exocrine elements The outcomes thus exhibit that Cyperus iria aqueous-ethanol 
extract significantly reduced histopathologic changes of STZ injection in rats. Results are depicted in Fig. $4(1,2,3)$

\section{Discussion}

Diabetes mellitus is a fatal metabolic ailment having micro and macro vascular complications that results in organ deterioration to chronic extent (Chakraborty et al. 2017). This chronic multifactorial disorder is correlated with excessive plasma glucose concentration (Srinivasan and Davies 2019). Antihyperglycemic, antioxidant and anti-inflammatory properties of Cyperus iria were established in the present study.

High levels of flavonoids and polyphenols were detected in the Cyperus iria aqueous ethanol extract in the present study. Risk of free radical mediated diseases like diabetes mellitus can be improved by consumption of antioxidants. Phenolic substances exhibited strong antioxidant properties probably by inactivation of lipid free radicals (Ismail et al. 2004). Phenolics have the ability to screen the antioxidant behavior of plants owing to the scavenging potential of hydroxyl groups in them. Flavonoids also possess the potential to scavenge oxidizing molecules, including oxygen in singlet form. Thus flavonoids can enhance the defensive system by diminishing the free radicals. Detection of Phenolic acids and flavonoids have also been reported previously in Cyperus genus (Augustus et al. 2015).

HPLC analysis confirmed the presence of Myercetin, Quercetin, Kaempferol and Ferulic acid in Cyperus iria aqueous-ethanol extract. These compounds are widely reported as potent antioxidants. Present study exhibited a high reducing capacity in FRAP assay. It is attributed to the scavenging of free radicals. This antioxidant capacity can be linked to the presence of unique functional groups of myrecitin which includes pyrone and two phenyl rings (Barzegar 2016). Presence of these phyto-constituents also exhibited a strong antioxidant activity in DPPH Assay with an $\mathrm{IC}_{50}$ of $39.85 \mu \mathrm{g} / \mathrm{mL}$. Phenolics are proposed to exhibit an ideal quenching in DPPH assay owing to the catechols present in quercetin (Khan et al. 2020).

Present study also revealed that aqua-ethanol extract of Cyperus iria possess the potential to inhibit alpha amylase enzyme. Presence of phenolics and flavonoids in the aqua-ethanol extract of Cyperus iria can be found associated with the enzyme inhibition. Phenolics possess the ability to form lactones which can react with nucleophilic groups of alpha amylase molecules whereas flavonoids lead to enhanced insulin release due to inhibition of alpha amylase (Zafar et al. 2020). Results are in accordance with previous study where compounds isolated from Cyperus rotundus rhizome inhibited alpha amylase enzyme (Tran et al. 2014)

OGTT indicated a decrease in area under curve exhibiting a decrease in blood glucose level. The delay in the apex glucose level reflects a change in absorption process. This change in absorption is linked with decreased expression of sodium glucose transport (SGLT-1). It suggests that a mechanism other than 
glycoside hydrolases is involved. Results are in accordance with previous studies where hypoglycemia in baseline conditions is found to be associated with closing of potassium and calcium channels in pancreatic beta cells (Malik et al. 2020).

A dose dependent decrease in glucose was exhibited in STZ induced diabetic rats by the aqueous-ethanol extract of Cyperus iria. High antioxidant potential of the plant can be a description of better antidiabetic effect. Many studies have reported that this genus possess antioxidant effect probably by controlling the over production of free radicals. The reduction in glucose level might be attributed to the detected myrecetin as it is responsible for the inhibition of I-kappa-B(IkB)/nuclear factor-kB (NF-KB) P65 signaling pathway (Gupta et al. 2020). Myrecetin also possess the ability to alter phosphorylation of insulin receptor, subsequently effecting glucose transporters sub type 4 (GLUT-4) translocation (Li and Ding 2012).It also possess the potential to protect the beta cells against high glucose induced apoptosis by inhibition of endoplasmic stress probably by inactivation of CDK5 and subsequent upregulation of PDX-1 and SER CA2b (Gupta et al. 2020). Similarly, Ferulic acid can scavenge superoxide anion radical effectively inhibiting the lipid peroxidation. Hydroxy and phenoxy groups of ferulic acid can donate electrons for the quenching of free radicals (Srinivasan et al. 2007). Present study exhibited a positive corroboration with the previous findings where it was claimed that flavonoids obtained from Cyperus rodentus rhizome exhibited anti diabetic activity in diabetic rats. Acute Oral toxicity exhibited the safety of aqueous-ethanol extract of Cyperus iria up to $2000 \mathrm{mg} / \mathrm{kg} \mathrm{BW}$.

Production of cytokines and pro-inflammatory markers have been associated with hyperglycemia. Advanced glycation products accumulation during hyperglycemia is associated with inflammation production. Expressions of pro-inflammatory cytokines such as IL-6 and TNF-a during hyperglycemia induced injury are raised (Malik et al. 2020). Aqueous-ethanol extract of Cyperus iria reduces the production of cytokines in a dose dependent manner. Anti-inflammatory response can be attributed to the presence of flavonoids and phenolic components present in the Cyperus iria extract. Present study is in accordance with the previous claim where Cyperus irius another species of the same genus was claimed to possess anti-inflammatory potential.

Diabetes mellitus is associated with diabetic nephropathy leading to renal morbidity and mortality. In this condition glomerular sclerosis and fibrosis occurs causing loss of proteins in urine. Decreased insulin concentrations leads to minimize energy obtained from carbohydrates and increases catabolism of proteins leading to dysfunction of glomerulus (Malik et al. 2020). Decrease in urea and creatinine values were observed in animals after treatment with Cyperus iria aqueous-ethanol extract.

Lipid metabolism is altered in diabetes. The control of lipid levels is also important along with the reduction of plasma glucose concentration to reduce the risks of diabetes. Hyperlipidemia hinders the transport of glucose into the cells resulting in lipids availability on the artery walls. HDL transports the fatty plaques to the liver. HDL increase and cholesterol and triglycerides decrease is considered to be a useful therapeutic application. Present study indicated a decrease in TG, LDL and increase in HDL levels upon treatment with Cyperus iria aqueous-ethanol extract. Results are in concurrence with previous 
findings where phenols and flavonoids have been found to be associated with reduced lipid profiles exhibiting hypolipidemic effect (Zafar et al. 2020). A.I is a simple, easily calculated parameter in assessing the risk of myocardial infarction, atherosclerosis and $T_{2} D M$. extract elevated HDL-C and decreased TG resulted in the improvement of A.I. The results are in concurrence with a previous finding where higher doses of hydro alcoholic extract of Cyperus scariosus showed increase in HDL levels and significant reduction in cholesterol, triglycerides, LDL, VLDL and atherogenic coefficient level (Chawda et al. 2014).

High levels of ALT, AST and ALP in diabetic rats can be correlated with elevated transaminases in diabetic patients. Liver helps in maintaining normal blood glucose levels. Glycogenolysis and increased hepatic glucose production occurs when the effect of insulin on liver is lost. In such condition, elevated levels of aminotransferases act as an indicator of hepatic injury. Aqueous-ethanol extract of Cyperus iria might be able to ameliorate the hepatic transaminases and phosphatase associated with the decrease in free fatty acid, peroxides in the serum and reduced oxidation (Harris 2005). The significant reduction in measures of ALT, AST and ALP in STZ induced diabetic rats was noted in the present study. Current investigation is in accordance with the previous study where Cyperus rotundus rhizomes, when given to diabetic animals, also lowered the measures of all hepatic enzymes (Singh et al. 2015)

Antioxidant enzymes like SOD and GSH-ST are considered primary line of antioxidant defense. Present study indicated that treatment of STZ induced diabetic rats with Cyperus iria aqueous-ethanol extract at $500 \mathrm{mg} / \mathrm{kg}$ dose expedite the activities of SOD and GSH-ST in plasma. Presence of phenolic acids and flavonoids in the plant extract might be responsible for improving oxidative stress because myrecetin, quercetin, ferullic acid and kaemperol increases the activity of GST and SOD. Myrecetin possess the potential to enhance the GST activity that catalyse the conjugation of glutathione (GSH) to a wide variety of endogenous and exogenous electrophilic compounds. Similarly SOD catalyzes the dismutation of superoxide anion $\left(\mathrm{O}_{2}\right.$ radical) into hydrogen peroxide $\left(\mathrm{H}_{2} \mathrm{O}_{2}\right)$, which is then degraded to $\mathrm{H}_{2} \mathrm{O}$ by CAT (Kandasamy and Ashokkumar 2013). Ferulic acid decreases the cell redox irregularities, kaemperferol prevents oxidative damage by inhibiting lipid peroxidation (Al-Numair et al. 2015) and quercetin was found to be effective in controlling postprandial blood glucose in STZ induced rats owing to reduction in the oxidative stress (Alam et al. 2014).

Histopathological studies of STZ induced diabetic sections of liver, kidney and pancreas showed an improvement in diabetic rats treated with STZ. Aqueous-ethanol extract of Cypeus iria at dose of 500 $\mathrm{mg} / \mathrm{kg}$ BW restored these alterations to normal in a dose dependent fashion.

\section{Conclusions}

Regulatory bodies prefer herbal drugs possessing good quality control. Previously Cyperus iria has not been validated for its folklore antidiabetic claim. Current investigation demonstrates the antidiabetic nature of Cyperus iria aqueous-ethanol extract in STZ induced diabetic rats and provides evidence which might be attributed to control of glycemic control in blood, cytokines production and oxidative stress 
parameters. In-vitro analysis exhibited a better alpha amylase inhibition. HPLC data being a quality control parameter also provides good correlation with anti-diabetic and antioxidant potential. Overall, present study suggests that Cyperus iria aqueous-ethanol extract can be used to treat hyperglycemia therapeutically.

\title{
Declarations
}

\section{Consent for Publication}

\author{
Not Applicable
}

\section{Competing interests}

All authors have read and approved the manuscript. "The authors declare that they have no competing interests"

\section{Ethics approval and consent to participate}

The study was conducted followed by the approval of Animal Ethical Committee (IREC-2019-87) in accordance with the NC3Rs ARRIVE Guidelines, adhere to ethical guidelines of The Basel Declaration, the International Council for Laboratory Animal Science (ICLAS) ethical guidelines, and Directive 2010/63/EU. All procedures followed were in accordance with the standards set forth in the eighth edition of "Guide for the Care and Use of Laboratory Animals" (grants.nih.gov/grants/olaw/guide-for-the-careanduse-of-laboratory-animals_prepub.pdf published by the National Academy of Sciences, The National Academies Press, Washington, D.C.)

\section{Availability of data and materials}

All data generated or analysed during this study are included in this published article AS supplementary files

\section{Funding}

None

\section{Authors contributions}

M.S performed the experimental work and participated in data interpretation. B.A and F.M participated in the data analysis, statistical analysis A.S, M.M and S.U conceived the study, carried out the experimental 
design and data interpretation, and prepared and revised the manuscript. All authors read and approved the final manuscript.

\section{References}

1. Ahmed S et al. (2017) Anti-oxidant activity of Pistachia khinjuk supported by phytochemical investigation Acta Pol Pharm 74:173-178

2. Al-Numair KS, Chandramohan G, Veeramani C, Alsaif MA (2015) Ameliorative effect of kaempferol, a flavonoid, on oxidative stress in streptozotocin-induced diabetic rats Redox Report 20:198-209 doi:10.1179/1351000214Y.0000000117

3. Alam MM, Meerza D, Naseem I (2014) Protective effect of quercetin on hyperglycemia, oxidative stress and DNA damage in alloxan induced type 2 diabetic mice Life Sciences 109:8-14 doi:https://doi.org/10.1016/j.lfs.2014.06.005

4. Amuri B, Maseho M, Simbi L, Okusa P, Duez P, Byanga K (2017) Hypoglycemic and Antihyperglycemic Activities of Nine Medicinal Herbs Used as Antidiabetic in the Region of Lubumbashi (DR Congo) Phytotherapy Research

5. Asmat U, Abad K, Ismail K (2016) Diabetes mellitus and oxidative stress-A concise review Saudi pharmaceutical journal 24:547-553

6. Augustus OK, Janet JO, Ebenezer TB, Ogboma UJ (2015) Antioxidant activities, total flavonoid and total phenolic contents of whole plant of Kyllinga erecta Shumach Journal of Food and Nutrition Research 3:489-494

7. Banik G, Bawari M, Choudhury MD, Choudhury S, Sharma G (2010) Some anti-diabetic plants of Southern Assam Assam University Journal of Science and Technology 5:114-119

8. Barkaoui M, Katiri A, Boubaker H, Msanda F (2017) Ethnobotanical survey of medicinal plants used in the traditional treatment of diabetes in Chtouka Ait Baha and Tiznit (Western Anti-Atlas), Morocco Journal of ethnopharmacology 198:338-350

9. Barzegar A (2016) Antioxidant activity of polyphenolic myricetin in vitro cell-free and cell-based systems Mol Biol Res Commun 5:87-95

10. Chakraborty M, Ahmed MG, Bhattacharjee A (2017) Potential pharmacodynamic and pharmacokinetic interaction of pomegranate juice and nateglinide against diabetis induced complications in rats Synergy 5:1-6

11. Chawda HM, Mandavia DR, Parmar PH, Baxi SN, Tripathi CR (2014) Hypolipidemic activity of a hydroalcoholic extract of Cyperus scariosus Linn. root in guinea pigs fed with a high cholesterol diet Chinese journal of natural medicines 12:819-826

12. Gupta G et al. (2020) Current Pharmacological Trends on Myricetin Drug Research

13. Harris EH (2005) Elevated liver function tests in type 2 diabetes Clinical diabetes 23:115-119

14. Imo C, Nwokwu CDU, Mamma E, Mayel MH, Kukoyi AJ, Apaji AD (2018) Effects of ethanolic extracts of Phoenix dactylifera fruit, Cyperus esculentus Nut and Cocos nucifera Nut on selected indices of 
kidney function in male albino rats. J Journal of Applied Sciences 18:116-121

15. Ismail A, Marjan ZM, Foong CW (2004) Total antioxidant activity and phenolic content in selected vegetables Food chemistry 87:581-586

16. Jones WP, Kinghorn AD (2006) Extraction of plant secondary metabolites. In: Natural products isolation. Springer, pp 323-351

17. Kamboj VP (2000) Herbal medicine Current science 78:35-39

18. Kandasamy N, Ashokkumar N (2013) Myricetin modulates streptozotocin-cadmium induced oxidative stress in long term experimental diabetic nephrotoxic rats Journal of Functional Foods 5:1466-1477 doi:https://doi.org/10.1016/j.jff.2013.06.004

19. Khan D, Sharif A, Zafar M, Akhtar B, Akhtar MF, Awan S (2020) Delonix regia a Folklore Remedy for Diabetes; Attenuates Oxidative Stress and Modulates Type II Diabetes Mellitus Curr Pharm Biotechnol

20. Li Y, Ding Y (2012) Minireview: Therapeutic potential of myricetin in diabetes mellitus Food Science and Human Wellness 1:19-25

21. Malik M, Sharif A, Hassan SU, Muhammad F, Khan HM, Akhtar B, Saeed M (2020) Amelioration of hyperglycaemia and modulation of pro-inflammatory cytokines by Tamarix gallica fractions in alloxan induced diabetic rats Archives of Physiology and Biochemistry:1-10 doi:10.1080/13813455.2020.1788099

22. Manukumar H, Shiva Kumar J, Chandrasekhar B, Raghava S, Umesha S (2017) Evidences for diabetes and insulin mimetic activity of medicinal plants: Present status and future prospects Critical reviews in food science and nutrition 57:2712-2729

23. Razzaque F et al. (2020) Tylophora hirsuta (Wall.) extracts ameliorates diabetes associated with inflammation in alloxan induced diabetic rats Endocrine, Metabolic \& Immune Disorders Drug Targets

24. Sabry MM, Mahmoud MM, Shoukry HS, Rashed L, Kamar SS, Ahmed MM (2019) Interactive effects of apelin, renin-angiotensin system and nitric oxide in treatment of obesity-induced type 2 diabetes mellitus in male albino rats Archives of physiology and biochemistry 125:244-254

25. Semwal M, Kumar A, Ramu N, Mandal T, Bhushan C, Shukla A (2016) Influence of pre and postemergent applied herbicides on weed dynamics, nutrients uptake and yield of pigeonpea (Cajanus cajan L.) International Journal of Bio-resource and Stress Management 7:705-711

26. Sharif A et al. (2016a) Pharmaceutical wastewater being composite mixture of environmental pollutants may be associated with mutagenicity and genotoxicity Environmental Science and Pollution Research 23:2813-2820

27. Sharif A, Ashraf M, Javeed A, Anjum AA, Akhtar MF, Akhtar B, Saleem A (2016b) Oxidative stress responses in Wistar rats on subacute exposure to pharmaceutical wastewater Environmental Science and Pollution Research 23:24158-24165

28. Shrestha S, Gyawali P, Shrestha R, Poudel B, Sigdel M (2008) Serum urea and creatinine in diabetic and non-diabetic subjects Journal of Nepal Association for Medical Laboratory Sciences P 11:12 
29. Singh P, Khosa RL, Mishra G, Jha KK (2015) Antidiabetic activity of ethanolic extract of Cyperus rotundus rhizomes in streptozotocin-induced diabetic mice Journal of pharmacy \& bioallied sciences 7:289

30. Srinivasan BT, Davies M (2019) Glycaemic management of type 2 diabetes Medicine 47:32-39

31. Srinivasan M, Sudheer AR, Menon VP (2007) Ferulic Acid: Therapeutic Potential Through Its Antioxidant Property Journal of Clinical Biochemistry and Nutrition 40:92-100 doi: $10.3164 /$ jcbn.40.92

32. Tran HHT et al. (2014) Inhibitors of a-glucosidase and a-amylase from Cyperus rotundus Pharmaceutical Biology 52:74-77 doi:10.3109/13880209.2013.814692

33. Zafar M, Sharif A, Khan D, Akhtar B, Muhammad F, Akhtar MF, Fatima T (2020) Preventive effect of Euphorbia royleana Boiss on diabetes induced by streptozotocin via modulating oxidative stress and deoxyribonucleic acid damage Toxin Reviews:1-14 doi:10.1080/15569543.2020.1780262

34. Zaib M et al. (2020) Berberis lycium Royle. extracts attenuate inflammation and modulates hyperglycemia in alloxan induced diabetic rats Pakistan Journal of Pharmaceutical Sciences

35. Zulfqar F, Akhtar MF, Saleem A, Akhtar B, Sharif A, Saleem U (2020) Chemical characterization, antioxidant evaluation, and antidiabetic potential of Pinus gerardiana (Pine nuts) extracts Journal of food biochemistry 44:e13199

\section{Figures}

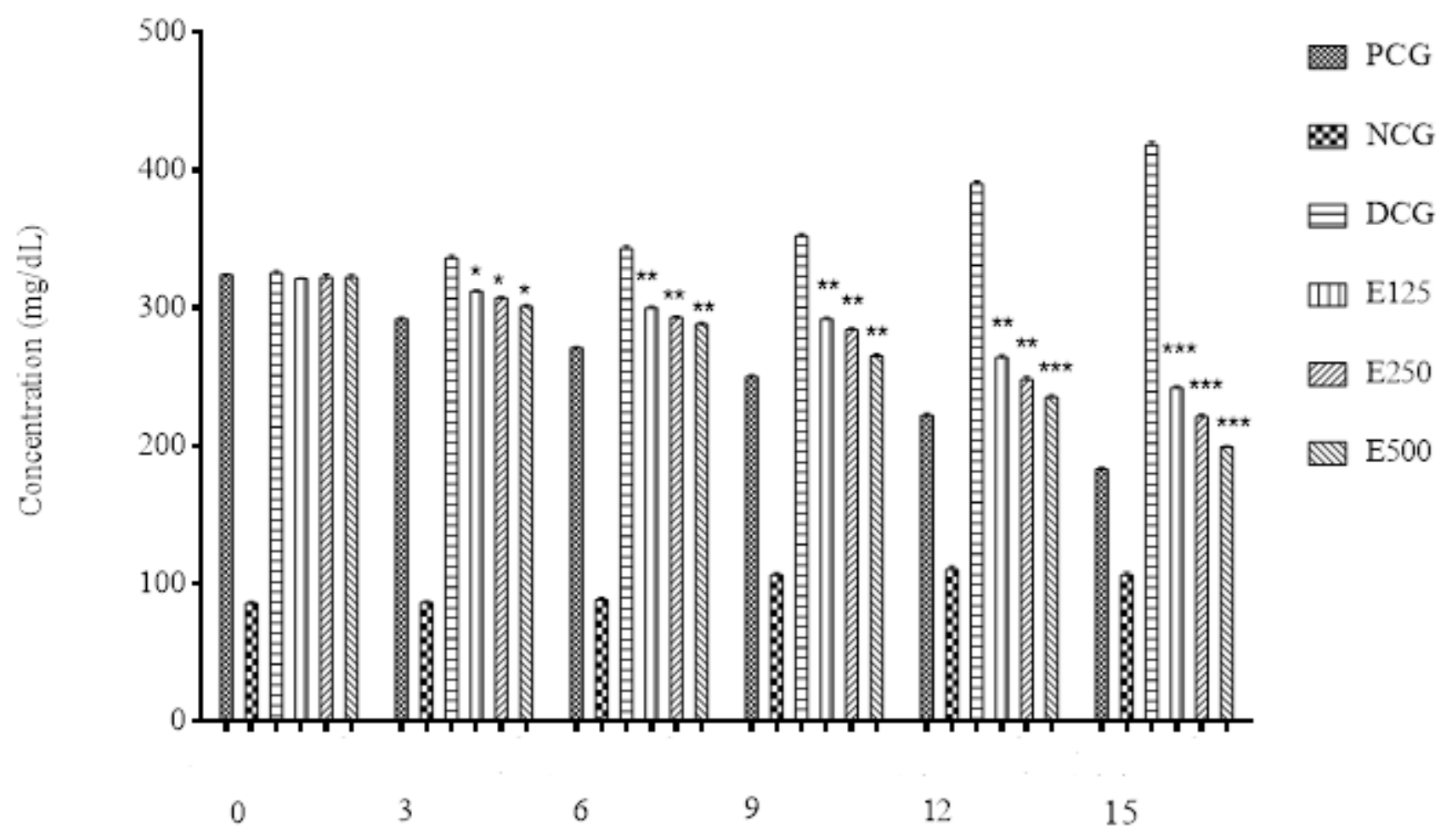

Days 
Figure 1

Anti-hyperglycemic effect of Cyperus iria aqueous-ethanol extract in streptozotocin induced diabetic rats. Values are expressed as Mean \pm SEM $(n=5)$. * shows $p<0.05, * \star p<0.01, * \star \star p<0.001$ in comparison to diabetic control group DCG.
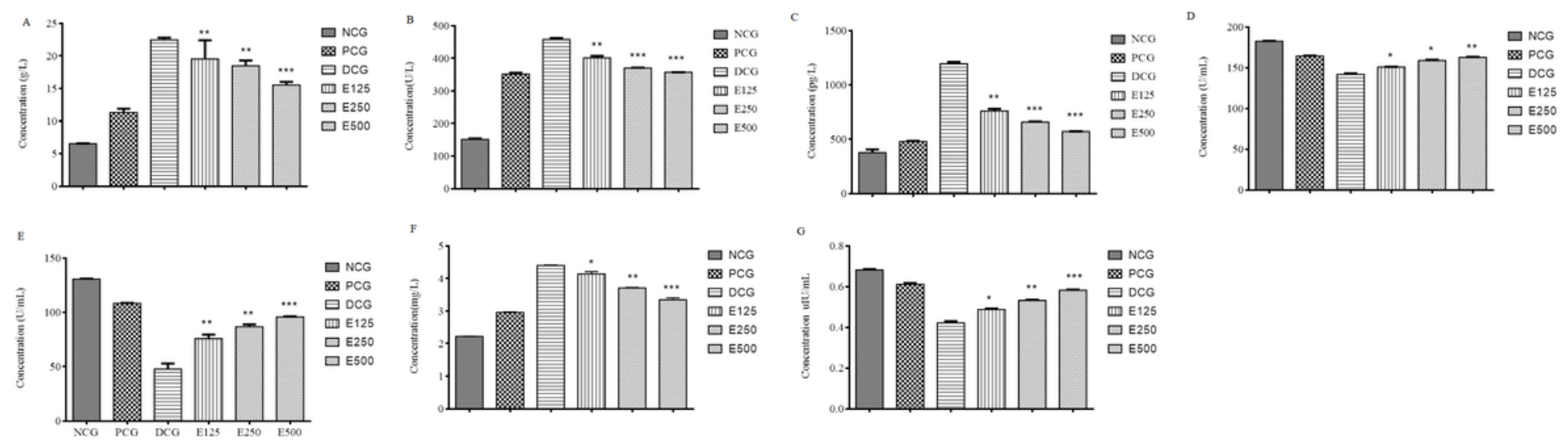

Figure 2

Effect of Cyperus iria aqueous-ethanol extract on streptozotocin induced diabetic rats A. Tumor necrosis factor (TNF-a) B. cyclooxygenase (COX-2) C. interleukin 6 (IL-6) D. superoxidedismutase (SOD) E. glutathione transferase (GSH-ST) F. C reactive proteins $\mathrm{G}$. Insulin Values are expressed as Mean $\pm \mathrm{SEM}$ $(n=5)$. * shows $p<0.05, * * p<0.01, * * * p<0.001$ in comparison to diabetic control group DCG.
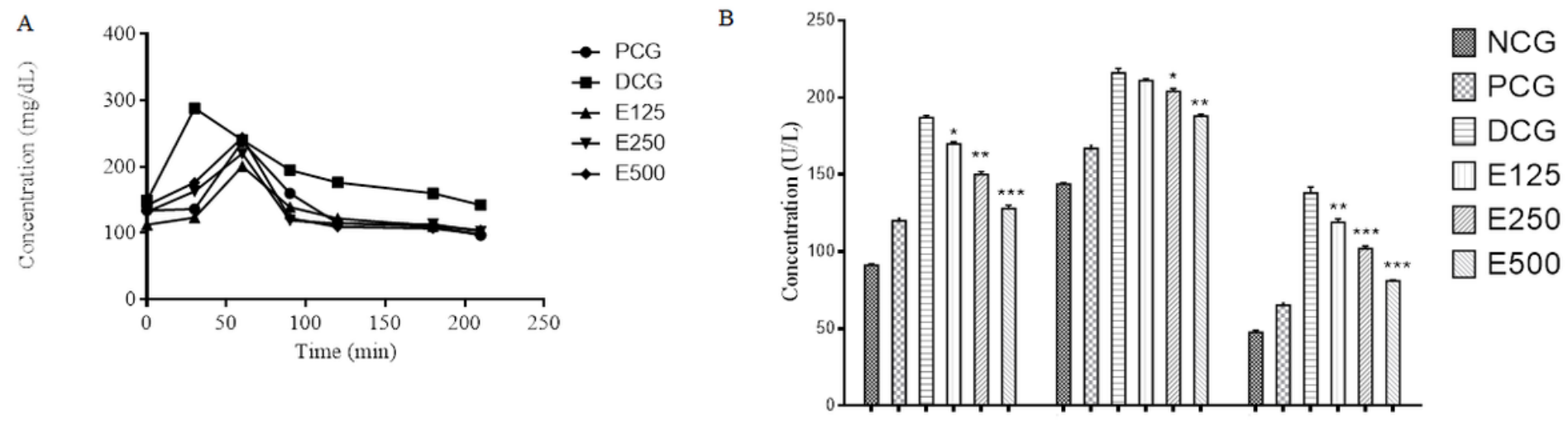

ALP $\quad$ AST $\quad$ ALT

\section{Figure 3}

(A) Effect of Cyperus iria aqueous ethanol extract on glucose tolerance level (OGTT) in normal rats (B) Effect of Cyperus iria aqueous ethanol extract on liver function test Values are expressed as Mean \pm SEM $(n=5) .{ }^{*}$ shows $p<0.05,{ }^{*} p<0.01, * \star \star p<0.001$ in comparison to diabetic control group DCG. 

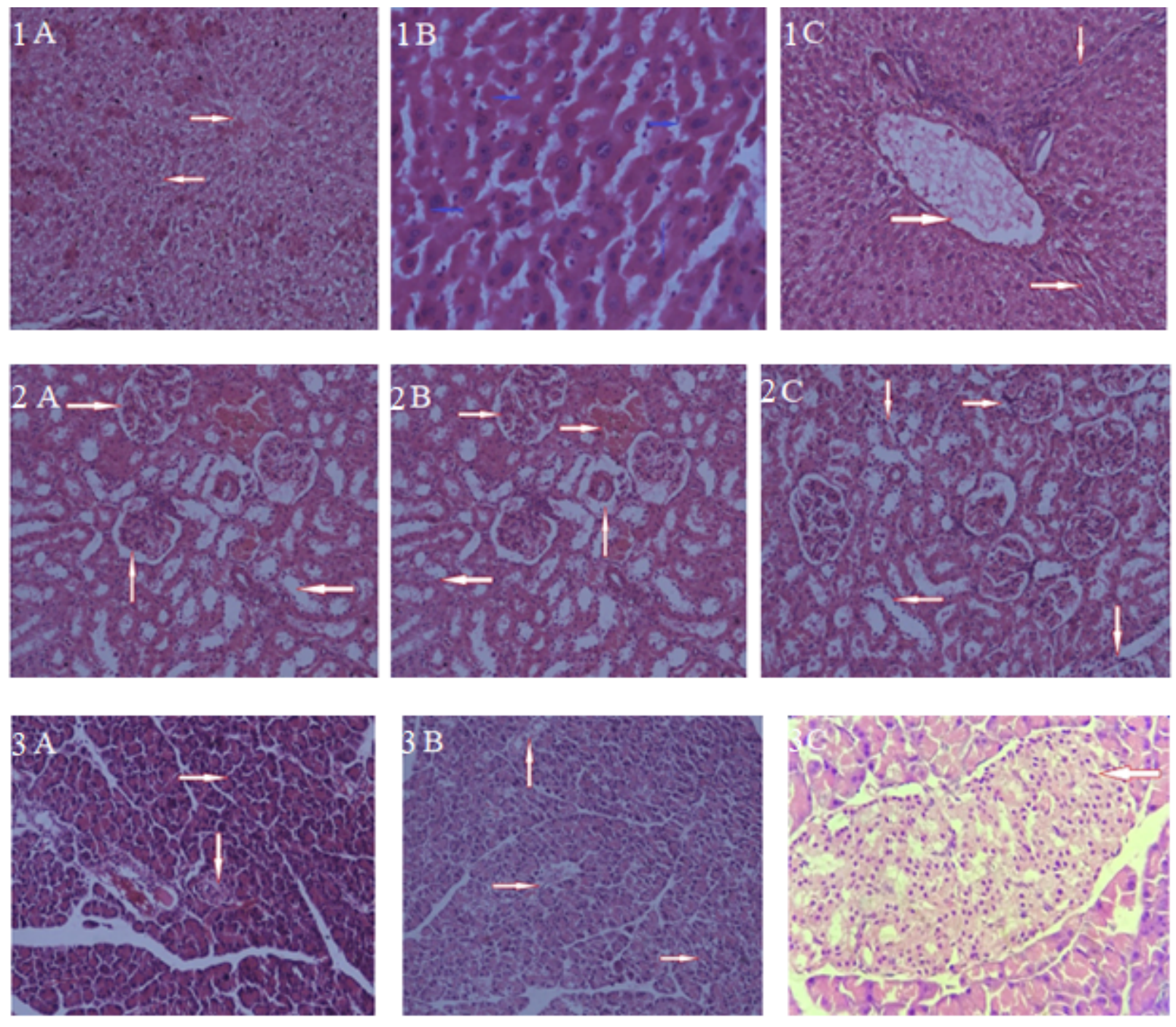

\section{Figure 4}

1. Histopathological study of liver section after treatment: A. Normal control exhibits normal hepatic architecture. no inflammation, atypia, hydropic degeneration, fibrosis, necrosis, Steatosis or malignancy was observed. B. Diabetic control exhibited hepatocytic degeneration in the peripheral zone. The hepatic injury was mild to moderate $\mathrm{C}$. After treatment with E500 liver revealed normal architechture of the tissue. Associated hyperplasia of the tubules with peritubular cuffing of lymphocytes was observed. Any degeneration, inflammation, fibrosis, necrosis, atypia and malignancy was not present. 2. Histopathological study of kidney section after treatment: A. Normal control exhibited disclosed normal renal capsule, nephrons and tubules B. Diabetic control revealed nephron degeneration. The glomeruli and glomerular tubules had started to degenerate. Any atypia or malignancy was not present C. After treatment with E500 foci of haemorrhages in the interstitium were observed. Eosinophilic hyaline casts were present in the tubular area. There was evidence of focal degeneration of proximal tubules. No renal tissue necrosis, tubular degeneration, fibrosis, atypia or malignant changes were seen. 3 .

Histopathological study of Pancreas after treatment: A. Normal control revealed normal looking endo-and exocrine elements of pancreas. The Islets of Langerhan contained normal looking Beta cells concentration. The acinar cells also appeared normal B. Diabetic control revealed congestion of 
vasculature and evident peripancreatitis. Beta cells were surrounded by aggregates of inflammatory cells. No evidence of atypia or malignancy was observed C. After treatment with E500 pancreatic tissue revealed normal looking exocrine elements. Islet of Langerhans was present in the endocrine element having moderate number of beta cells and acinar cells concentration. Degeneration of beta cells was minimal. Any evidence of inflammation, calcification, granuloma and malignancy was not observed.
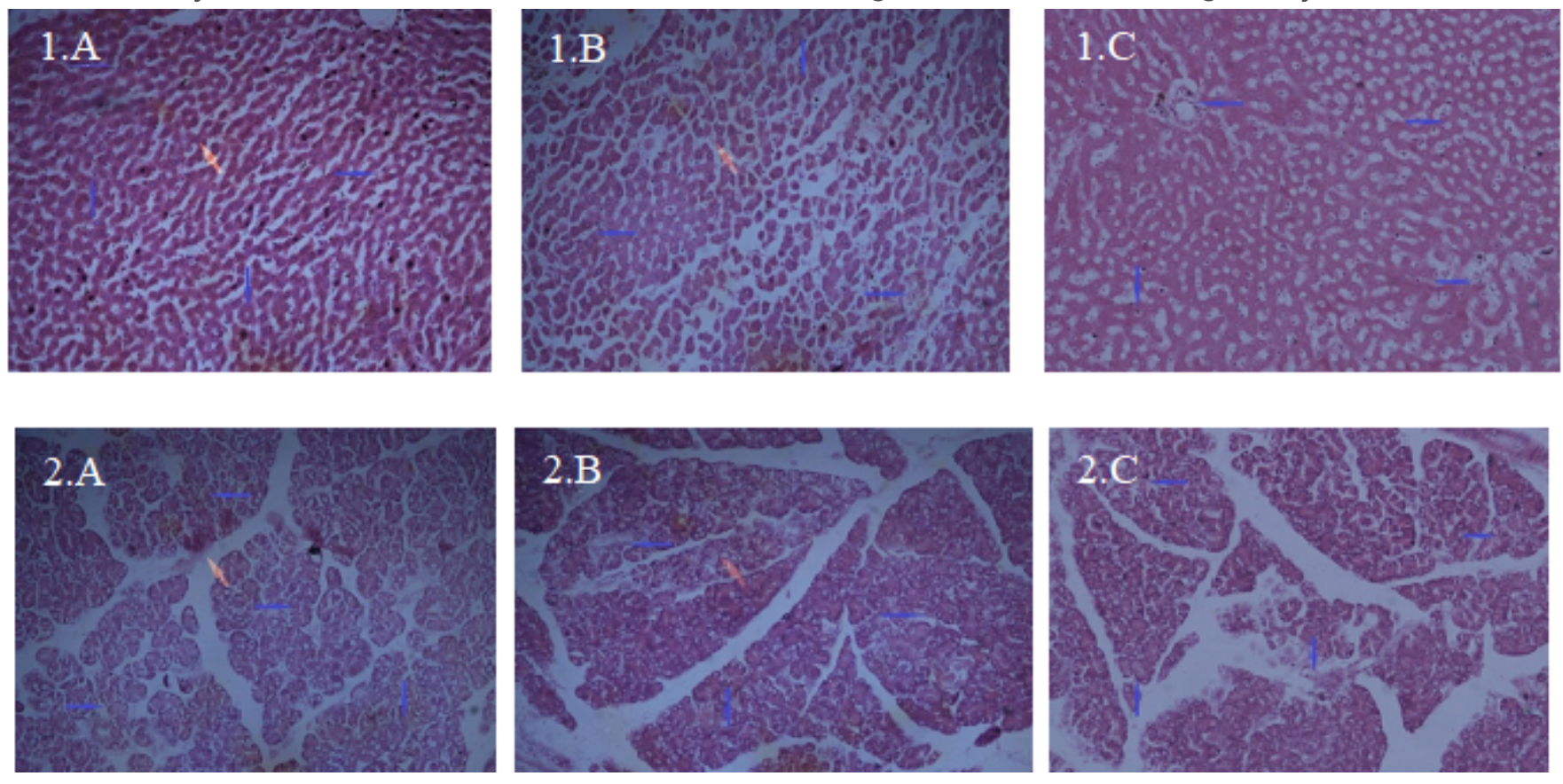

\section{Figure 5}

1. Histopathological study of liver section in acute toxicity: A. Normal control exhibited normal hepatic architecture, cellular appearance and vascularity B. Rats given $2000 \mathrm{mg} / \mathrm{kg}$ extract showed mild hepatocytic degeneration. The aggregated inflammatory cells were present around the hepatic rim. Any atypia and malignancy was not observed C. Rats given $5000 \mathrm{mg} / \mathrm{kg}$ extract exhibited moderate hepatocytic degeneration. The aggregated inflammatory cells were prominent around the hepatic rim. Hepatic array appeared normal. Any atypia and malignancy was not observed. 2. Histopathological study of pancreas in acute toxicity: A. Normal control showed normal looking endocrine and exocrine pancreatic elements. $\beta$-cells concentration was normal. Normal acinar cells were also seen $B$. Rats given $2000 \mathrm{mg} / \mathrm{kg}$ extract exhibited normal looking pancreatic exocrine elements were seen in pancreatic section. The endocrine element exhibited close to normal $\beta$ and acinar cells. Any degeneration, inflammation, malignancy, granuloma and calcification were not observed C. Rats given $5000 \mathrm{mg} / \mathrm{kg}$ extract exhibited moderate degeneration of Islet cells. Pancreatic lobules were surrounded by cleavage of inflammatory cells. Any atypia and malignancy was not observed.

\section{Supplementary Files}

This is a list of supplementary files associated with this preprint. Click to download.

- SupplementryFile.docx 